Article title: Resource availability and disturbance shape maximum tree height across the Amazon

Authors:

Eric Bastos Gorgens. Correspondent author. Universidade Federal dos Vales do Jequitinhonha e Mucuri. Rodovia MGT 367 - Km 583, nº 5.000. Departamento de Engenharia Florestal. Campus JK, Alto da Jacuba, Diamantina, Minas Gerais, Brazil. CEP 39100-000. Email: eric.gorgens@ufvjm.edu.br

Matheus Henrique Nunes. University of Helsinki. mhnunes1987@gmail.com

Tobias Jackson. University of Cambridge. tobydjackson@gmail.com

David Coomes. University of Cambridge.dac18@cam.ac.uk

Michael Keller. United States Forest Service. mkeller.co2@gmail.com

Cristiano Rodrigues Reis. Universidade de São Paulo.crreis28@gmail.com

Ruben Valbuena. Bangor University. r.valbuena@bangor.ac.uk

Jacqueline Rosette. Swansea Univesity. j.a.rosette@swansea.ac.uk

Danilo Roberti Alves de Almeida. Universidade de São Paulo. daniloraa@usp.br

Bruno Gimenez. Smithsonian Tropical Research

Institute. bruno.oliva.gimenez@gmail.com

Roberta Cantinho. Universidade de Brasília.rzcantinho@gmail.com

Alline Zagnolli Motta. Universidade Federal dos Vales do Jequitinhonha e Mucuri. allinezvm@gmail.com

Mauro Assis. Instituto Nacional de Pesquisas Espaciais. assismauro@hotmail.com

Francisca Rocha de Souza Pereira. Instituto Nacional de Pesquisas Espaciais. franrspereira@gmail.com

Gustavo Spanner. Instituto Nacional de Pesquisas da Amazônia. gustavo.spanner@gmail.com

Niro Higuchi. Instituto Nacional de Pesquisas da Amazônia.

higuchi.niro@gmail.com

Jean Pierre Ometto. Instituto Nacional de Pesquisas Espaciais.

jeanometto@gmail.com 
Statement of authorship: EBG, TJ, DC, MK, NH, MHN, JO conceived of the idea. EBG, MA, GS, FSP, AZM developed the analysis and performed the computations. EBG, MHN, TJ, MK, DV, RV, NH, CRR, RC, DAA, JR, BG, JO verified the results, interpreted the results, and wrote the manuscript.

Data accessibility statement: The authors confirm that the data supporting the results will be archived in Zenodo.org and the data DOI is already included into the paper.

Keywords: sentinel tree, tree height, giant trees, dominant tree, tree distribution 


\section{Resource availability and disturbance shape maximum tree height across the Amazon}

2 Tall trees are key drivers of ecosystem processes in tropical forest, but the controls on the

3 distribution of the very tallest trees remain poorly understood. The recent discovery of grove of

4 giant trees over 80 meters tall in the Amazon forest requires a reevaluation of current thinking.

5 We used high-resolution airborne laser surveys to measure canopy height across 282,750 ha of

6 old growth and second growth forests randomly sampling the entire Brazilian Amazon. We

7 investigated how resources and disturbances shape the maximum height distribution across the

8 Brazilian Amazon through the relations between the occurrence of giant trees and environmental

9 factors. Common drivers of height development are fundamentally different from those

10 influencing the occurrence of giant trees. We found that changes in wind and light availability

11 drive giant tree distribution as much as precipitation and temperature, together shaping the

12 forest structure of the Brazilian Amazon. The location of giant trees should be carefully

13 considered by policymakers when identifying important hotspots for the conservation of

14 biodiversity in the Amazon.

\section{Introduction}

16 The Amazon is the largest tropical forest on Earth, covering 5.5 million square kilometers, and

17 storing $\sim 17 \%$ of all vegetation carbon (Feldpausch et al., 2012). Ecologists have long taken an

18 interest in comparing forest structure across the tropics (Yang et al., 2016), and have reached a

19 consensus that the Amazon supports shorter trees, and therefore stores a lower amount of carbon

20 per hectare, than the forests of tropical Africa and Asia (Cao \& Woodward, 2002; Feldpausch et

21 al., 2012). Previous studies have shown the occurrence of tall canopy regions in the Amazon and 
debated the factors that govern Amazon tree growth (Lefsky 2010; Simard et al., 2011; Larjavaara, 2013; Tao et al., 2016a). However, the recent confirmation of the existence of giant trees - up to $88 \mathrm{~m}$ tall - in the Amazon basin (Gorgens et al., 2019) challenges some paradigms and poses new questions about the drivers causing the spatial distribution of tall trees, and consequently about how maximum tree height is controlled across different regions.

To reach immense size, trees must fulfill at least three conditions: They must (1) have evolved to be capable of transporting water to great heights overcoming highly negative water potentials (Koch et al., 2004; Niklas, 2007; McDowell et al., 2008); (2) inhabit an area with environmental conditions (such as climate, soil properties, and water) that meet species-specific requirements (Scheffer et al., 2018) and (3) grow in regions with a low frequency of natural or anthropogenic disturbance events (Larjavaara, 2013; Lindenmayer \& Laurance, 2016; Scheffer et al., 2018; Enquist et al., 2020).

Height growth is partly governed by local factors such as water availability, temperature, rooting depth, and soil type (Anderegg et al., 2016; McDowell \& Allen, 2015; Coomes et al., 2006; Niklas, 2007), with precipitation and potential evapotranspiration consistently reported as key factors determining plant height across biomes (Moles et al., 2009; Larjavaara, 2013; Rueda et al., 2016). Resource availability (e.g. sunlight, nutrients, $\mathrm{CO}_{2}$, and water) controls a tree's ability to produce biomass from the products of photosynthesis. In contrast, natural disturbances (e.g. wind-throw, drought, or lightning and anthropogenic actions (e.g. selective logging, forest fragmentation) increase the likelihood of mortality and limit the time available for trees to grow taller (Bennett et al., 2015; Yanoviak et al., 2019; Almeida et al., 2019; Powers et al., 2020). Species of tall trees are likely to have evolved strategies for surviving diseases and 
pathogens (van Gelder et al., 2006; Aleixo et al., 2019) as well as climatic fluctuations (Sakschewski et al., 2016) and resisting wind damage (Jagels et al., 2018).

The sheer size of the Amazon, its environmental heterogeneity, and species diversity pose challenges and practical difficulties to understand general ecological relationships and biogeographical patterns (Tuomisto et al., 2019). Forest inventory plots provide many valuable insights to investigate the influences of the environment on tree height but they only represent a minuscule fraction of the total forest area (Chave et al., 2020). Currently, a network of 5,351 forest inventory plots established across the Brazilian Amazon, of known and published sites recently compiled by (Tejada et al., 2019), represents only $0.0013 \%$ of the total forest area in this region. In addition, the plot distribution is spatially clustered in close proximity to major roads or large rivers (Stropp et al., 2020), implying a spatial distribution bias (Marvin et al., 2014). About $42 \%$ of the Brazilian Amazon lies over $50 \mathrm{~km}$ from the nearest forest inventory plots (Tejada et al., 2019). Remote sensing can remove sampling biases and uncertainty about ecological patterns (Schimel et al., 2015) and provides large datasets to uncover the environmental controls of forest structure (Asner et al., 2010). In particular airborne lidar (light detection and ranging) generates valuable high-resolution 3D information of forest canopy structure (Görgens et al., 2016; Coomes et al., 2017), and can provide a link between field and satellite data (Asner, 2009; Bae et al., 2019).

In this study, we employed the largest airborne lidar data collection in the Amazon to contribute to the understanding of (1) how resources and disturbances shape the maximum height distribution across the Brazilian Amazon, and (2) what drives the occurrence of giant trees (taller than 70 meters). We conducted an extensive analysis relating environmental variables to the maximum height recorded in lidar transects. 
Between 2016 and 2018, the EBA airborne missions (conducted by the Brazilian National Institute for Space Research (INPE) and funded by Amazon Fund) collected airborne lidar data from 906 transects of 375 ha $(12.5 \times 0.3 \mathrm{~km})$ each. A majority of the transects were flown over randomly selected locations of old growth and second growth as forests defined by the PRODES and TerraClass databases (PRODES, INPE, 2016; TerraClass, INPE, 2014). PRODES separates forests from non-forest while TerraClass identifies second growth forest and other land covers. A small number of transects intentionally overlapped existing field plots for biomass calibration. Details about lidar processing and the EBA project characteristics have been published previously (see supplementary material from Gorgens et al. 2019). Briefly, the average pulse density was 4 pulses $\mathrm{m}^{-2}$, the field of view equal to $30^{\circ}$, and the nominal flying altitude of $600 \mathrm{~m}$ above ground. The pulse footprint was less than $30 \mathrm{~cm}$ at range.

For each transect we identified the returns from the ground and vegetation. We interpolated ground returns to produce a $1 \mathrm{~m}$ horizontal resolution digital terrain model (DTM). Using the DTM, we calculated the heights above ground from vegetation returns. The uppermost vegetation heights were then employed to compute a $1 \mathrm{~m}$ horizontal resolution canopy height model (CHM). While errors in estimation of terrain height can affect CHM estimations, previous studies in tropical forests show that lidar surveys with at least 4 returns per $\mathrm{m}^{2}$ permit accurate DTM generation and tree height estimation even in complex terrain (Clark et al., 2004; Glenn et al., 2011; Leitold et al. 2015; Andrade et al., 2018).

Our analysis was based on the tallest tree for each transect. A forest consists of plants that occur in different combinations over the landscape, and each individual is sensitive to certain aspects 
of the environment (Vanclay, 1992). The soil (fertility, drainage), climate (temperature and rainfall patterns), topography (altitude, aspect), and other factors can only give a general indication of site productivity because they fail to account for any local variations in the site (e.g. the species present) (Binkley et al., 2004). Site comparisons should depend upon indicators not unduly influenced by stand condition, land use history, or diversity. For sites that are sufficiently large, the maximum height that a species is likely to attain is an excellent indicator of site conditions for tree growth (Daubenmire, 1976). Therefore we selected a single tallest tree per transect using an individual tree approach based on a local maximum filter. For each transect, the largest tree was inspected to exclude spurious maxima not related to tree structure. (Supplementary Figure 1).

\section{Environmental variables}

In order to investigate drivers influencing the spatial distribution of giant trees, we initially considered a total of 18 environmental variables: (1) fraction of absorbed photosynthetically active radiation (FAPAR; in \%); (2) elevation above sea level (elevation; in m); (3) the component of the horizontal wind towards east, i.e. zonal velocity (u-speed ; in $\mathrm{m} \mathrm{s}^{-1}$ ); (4) the component of the horizontal wind towards north, i.e. meridional velocity (v-speed ; in $\left.\mathrm{m} \mathrm{s}^{-1}\right)$; (5) the number of days not affected by cloud cover (clear days; in days $\mathrm{yr}^{-1}$ ); (6) the number of days with precipitation above $20 \mathrm{~mm}$ (days $>20 \mathrm{~mm}$; in days $\mathrm{yr}^{-1}$ ); (7) the number of months with precipitation below $100 \mathrm{~mm}$ (months $<100 \mathrm{~mm}$; in months $\mathrm{yr}^{-1}$ ); (8) lightning frequency (flash rate $\left.\mathrm{yr}^{-1}\right) ;(9)$ annual precipitation (in $\left.\mathrm{mm} \mathrm{yr}^{-1}\right) ;(10)$ annual potential evapotranspiration (in mm $\left.\mathrm{yr}^{-1}\right) ;(11)$ coefficient of variation of monthly precipitation (precipitation seasonality; in \%); (12) amount of precipitation on the wettest month (precip. wettest; in mm month ${ }^{-1}$ ); (13) amount of 
112 precipitation on the driest month (precip. driest; in $\mathrm{mm} \mathrm{month}^{-1}$ ); (14) mean annual temperature

113 (in ${ }^{\circ} \mathrm{C}$ ); (15) standard deviation of monthly temperature (temp. seasonality; in ${ }^{\circ} \mathrm{C}$ ); (16) annual

114 maximum temperature (in ${ }^{\circ} \mathrm{C}$ ); (17) soil clay content (in \%); and (18) soil water content

115 (volumetric \% at field capacity at $30 \mathrm{~cm}$ ). Data sources are described in the following

116 paragraphs and are listed in Table 1.

117 The FAPAR was derived from land surface reflectance product calibrated and corrected from the 118 National Oceanic and Atmospheric Administration's (NOAA) Advanced Very High-Resolution 119 Radiometer (AVHRR), which is a consistent time-series dataset spanning from the mid-1980s to 120 present and suitable for climate studies (Tao et al., 2016b). FAPAR is a primary vegetation 121 variable controlling the photosynthetic activity of plants and is considered an essential climate 122 variable (Mason et al., 2010).

123 The elevation was based on the third version of the Shuttle Radar Topography Mission (SRTM) 124 provided by the National Aeronautics and Space Administration Jet Propulsion Lab (NASA 125 JPL) (Farr et al., 2007; Liu et al., 2014). The SRTM mission collected data during ten days of 126 operations, using two synthetic aperture radars: NASA's C band system (5.6 cm wavelength) and 127 an X band system supplied by DLR $(3.1 \mathrm{~cm})$. C-band partially penetrates the vegetation canopy, 128 with depth varying with vegetation structure. Because Amazonian vegetation is dense throughout, 129 for the purposes of this study the C-band DEM is assumed to vary consistently with topography 130 across the region.

131 We used the maximum daily mean wind speeds over the last 5 years from the fifth major global 132 reanalysis (ERA5) produced by the European Centre for Medium-Range Weather Forecasts 133 (ECMWF). The reanalysis combined model data with observations from across the world into a 134 globally complete and consistent dataset (Olauson, 2018). Two wind velocities were considered: 
u-speed which is the zonal velocity (i.e. the component of the horizontal wind towards east), and $\mathrm{v}$-speed which is the meridional velocity (i.e. the component of the horizontal wind towards north). These products are used extensively for modeling wind power both in academia and industry (Olauson, 2018; Albergel et al., 2019; Ramon et al., 2019). Although the ERA5 wind product gives mean wind speeds, means are related to extreme wind speeds by a Weibull distribution (Takle \& Brown, 1978; Seguro \& Lambert, 2000). Therefore a long-term variation in mean wind speed will correspond to variability and trends in extremes. ERA5 does not ingest surface winds from land stations to compute the wind speeds. Instead, ERA5 winds are estimated in planetary boundary layer schemes based on surface characteristics (Ramon et al., 2019).

The number of clear days was computed based on Moderate Resolution Imaging Spectroradiometer (MODIS) surface reflectance products. MODIS products provide an estimate of the surface spectral reflectance as it would be measured at ground level in the absence of atmospheric scattering or absorption (Kang et al., 2005; Bisht \& Bras, 2010). We used the Terra MOD09GA Version 6 product, which provides an estimate of the surface spectral reflectance of MODIS, corrected for atmospheric conditions.

Temperature and precipitation were obtained from the WorldClim database of bioclimatic variables, which are derived from weather station data compiled for the 1950-2000 period (Hijmans et al., 2005; Fick \& Hijmans, 2017). The main source of data was the Global Historical Climatology Network (GHCN), complemented with other global, national, regional, and local data sources, which were added if they were further than $5 \mathrm{~km}$ away from stations already included in the GHCN.

The lightning frequency was provided by the Lightning Imaging Sensor (LIS) instrument onboard the Tropical Rainfall Measuring Mission provided by NASA Earth Observing System 
Data and Information System (EOSDIS) Global Hydrology Resource Center. The LIS provided

159 the basis for the development of a comprehensive global thunderstorm and lightning climatology

160 to detect the distribution and variability of total lightning occurring in the Earth (Albrecht et al.,

161 2016).

162 The potential evapotranspiration was provided by the TerraClimate dataset, a global monthly

163 climate and water balance for terrestrial surfaces spanning 1958-2015. The layer combined high-

164 spatial-resolution climatological normals from WorldClim with Climate Research Unit (CRU)

165 Ts4.0 and the Japanese 55-year Reanalysis (JRA-55) data. The reference evapotranspiration was

166 calculated using the Penman-Monteith approach (Abatzoglou et al., 2018).

167 The number of months per year with precipitation below $100 \mathrm{~mm}$ and the number of days per

168 year with precipitation above $20 \mathrm{~mm}$ were computed based on the Climate Hazards Group

169 InfraRed Precipitation with Station data (CHIRPS) dataset. CHIRPS incorporated $0.05^{\circ}$

170 resolution satellite imagery with in-situ station data to create gridded rainfall time series for trend

171 analysis and seasonal drought monitoring (Funk et al., 2015).

172 Edaphic variables were obtained from The OpenLandMap produced by the OpenGeoHub

173 Foundation and contributing organizations. The clay content $(\%$ fine particles $<2 \mu \mathrm{m})$ and water

174 content layers (volumetric $\%$ at field capacity at $30 \mathrm{~cm}$ ), both with a spatial resolution of $250 \mathrm{~m}$,

175 were created based on machine learning predictions from a global compilation of soil profiles

176 and samples (Arsanjani et al., 2014).

177 To help visualize regional effects, we followed a biogeographic analyses of terrestrial plant and

178 animal taxa that divides the Brazilian Amazon into eight regions of Morrone (2014). This

179 classification of the Neotropical region and seeks to provide a universal, objective, and stable 
180 classification for describing distributions of taxa or comparing different biogeographic analyses

181 (Morrone, 2014).

Random Forests and Maximum Entropy

183 To explore the influence and importance of the environmental variables for development in tree 184 height, we employed a machine learning approach called "random forests" (Breiman, 2001). The 185 algorithm implemented in the $\mathrm{R}$ package randomForest (Liaw \& Wiener, 2002) generates a large 186 number of regression trees, each constructed considering a random data subset. The regression 187 trees are used to identify the best sequence for splitting the solution space to estimate the output 188 using $\mathrm{k}$-fold $(\mathrm{k}=15)$ cross-validation and 500 classification and regression trees. The number of 189 variables randomly sampled as candidates at each split was set to 2 . Using the coordinates of the 190 tallest tree within each LiDAR transect, we performed a simple extraction of the values for all 191 variable layers. Among the initial 18 environmental variables, two of them (precipitation of 192 driest month and months $<100 \mathrm{~mm}$ ) were excluded due to high correlation $(\mathrm{r}>0.80)$ to other 193 independent variables. Tree height was then modeled with the 16 remaining variables. The 194 adjusted model was evaluated considering the mean absolute error (MAE), root mean squared 195 error (RMSE), and coefficient of determination $\left(\mathrm{R}^{2}\right)$ of cross-validated predicted versus observed

196 values. To assess the overall relative variable importance, we used the mean increase in accuracy.

197 We visualized the relations of the environmental variables to maximum height using marginal 198 plots, estimating the maximum height by one variable at a time, keeping other variables constant 199 at an average value. The resulting model was implemented to map estimated maximum tree 200 heights across the Amazon. 
201 Focusing on the tallest trees - giants over $70 \mathrm{~m}$ in height - we built an environmental envelope

202 model to assess the conditions which favor their occurrence. We employed the maximum

203 entropy approach (MaxEnt) commonly applied to modelling species geographic distributions

204 with presence-only data to discriminate suitable versus unsuitable areas (Phillips et al., 2006).

205 The importance of variables in the MaxEnt model (measured as increase in accuracy) was used

206 to indicate the most relevant characteristics associated with giant trees and the potential locations

207 for their occurrence. In its optimization routine, the algorithm tracks model improvement when

208 small changes were made to each coefficient value associated with a particular variable. Each

209 variable was then ranked based on the proportion of all contributions. The resulting MaxEnt

210 model was implemented using the same 16 environmental variables described above to produce

211 a map of the probability of occurrence for giant trees taller than $70 \mathrm{~m}$ across the Brazilian

212 Amazon.

\section{Results}

214 The height distribution of the tallest individual trees selected for further analysis is presented in

215 Fig. 1. Trees exceeding $50 \mathrm{~m}$ were registered in 540 transects, widely distributed across the

216 Brazilian Amazon in all eight biogeographic regions (Fig 2). Within that set of transects, only 23

217 had giant trees above $70 \mathrm{~m}$ and only 6 registered trees above $80 \mathrm{~m}$. The distribution of the giant

218 trees is concentrated in the eastern Amazon in the Roraima and Guianan Lowlands

219 biogeographic regions (Fig 2). 


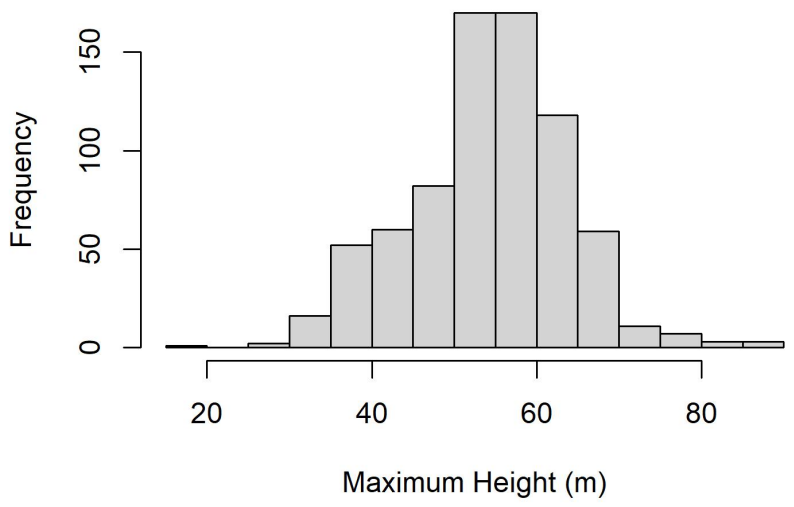

221

222 Figure 1. Maximum tree height distribution of the 906 trees extracted from the 906 airborne 223 lidar transects distributed across the Brazilian Amazon. 

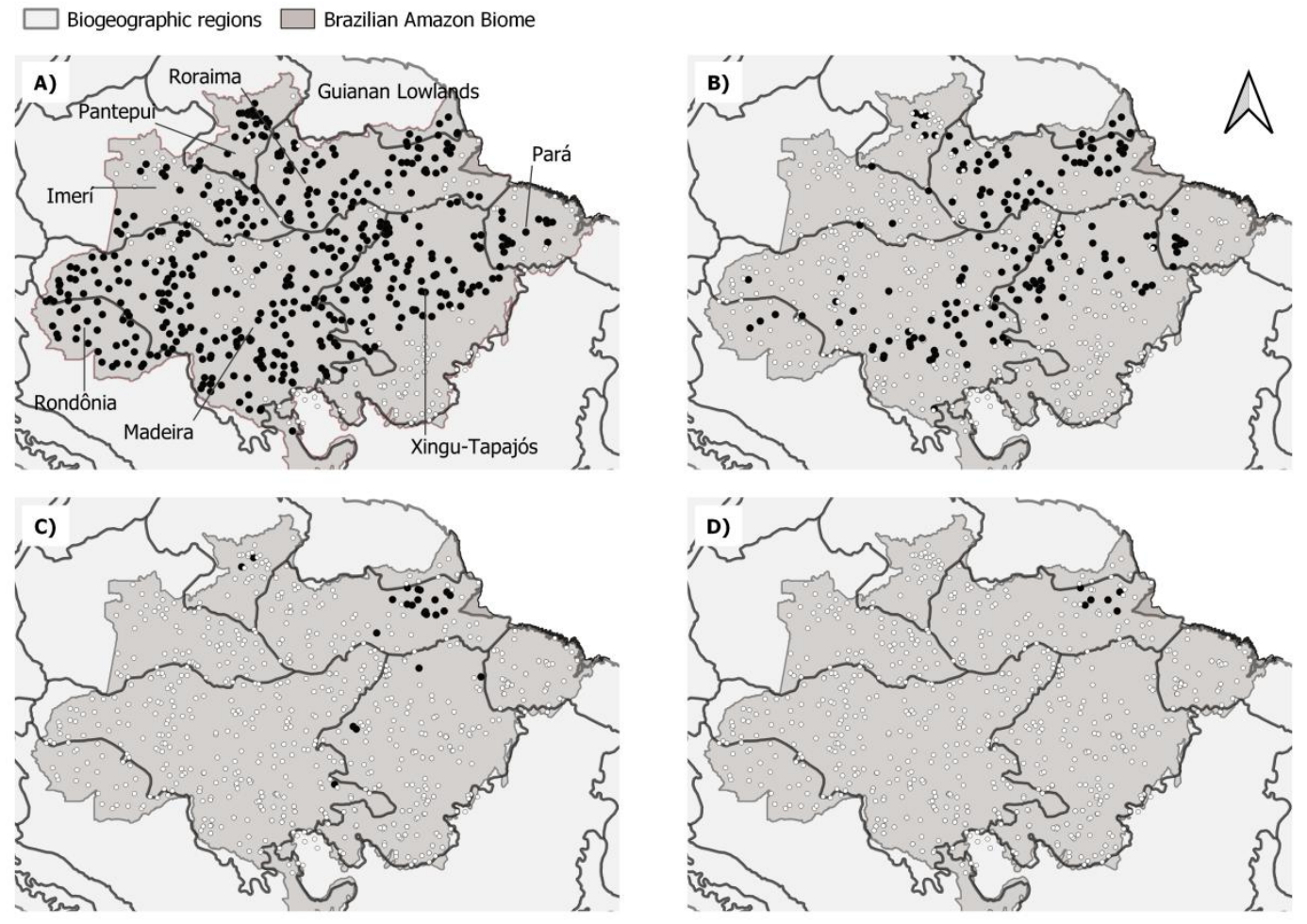

Figure 2. Maps of the Brazilian Amazon and biogeographic regions showing the location of transects considering height thresholds: (a) $50 \mathrm{~m}$, (b) $60 \mathrm{~m}$, (c) $70 \mathrm{~m}$, and (d) $80 \mathrm{~m}$. Black circles

227 indicate transects with trees taller than the threshold, white circles indicate remaining transects. 
229 The variables with the most explanatory power (based on increase in accuracy) in the random

230 forests model were $\left(1^{\text {st }}\right)$ the number of clear days, followed by $\left(2^{\text {nd }}\right)$ clay content in the soil and

$231\left(3^{\text {rd }}\right)$ elevation. The difference between the $4^{\text {th }}$ and the $15^{\text {th }}$ positions of the importance rank was

232 less than 6 units, ranging from 22.4 to 15.6 . The variable soil water content $\left(16^{\text {th }}\right)$ was the

233 weakest predictor (Table 1). Predictor variable importance could also be measured by an

234 alternative metric node purity that generally correlated with the increase in accuracy

235 (Supplementary Figure 2).

237 Table 1. Variables used to estimate maximum height ranked by variable importance results in

238 the random forests model

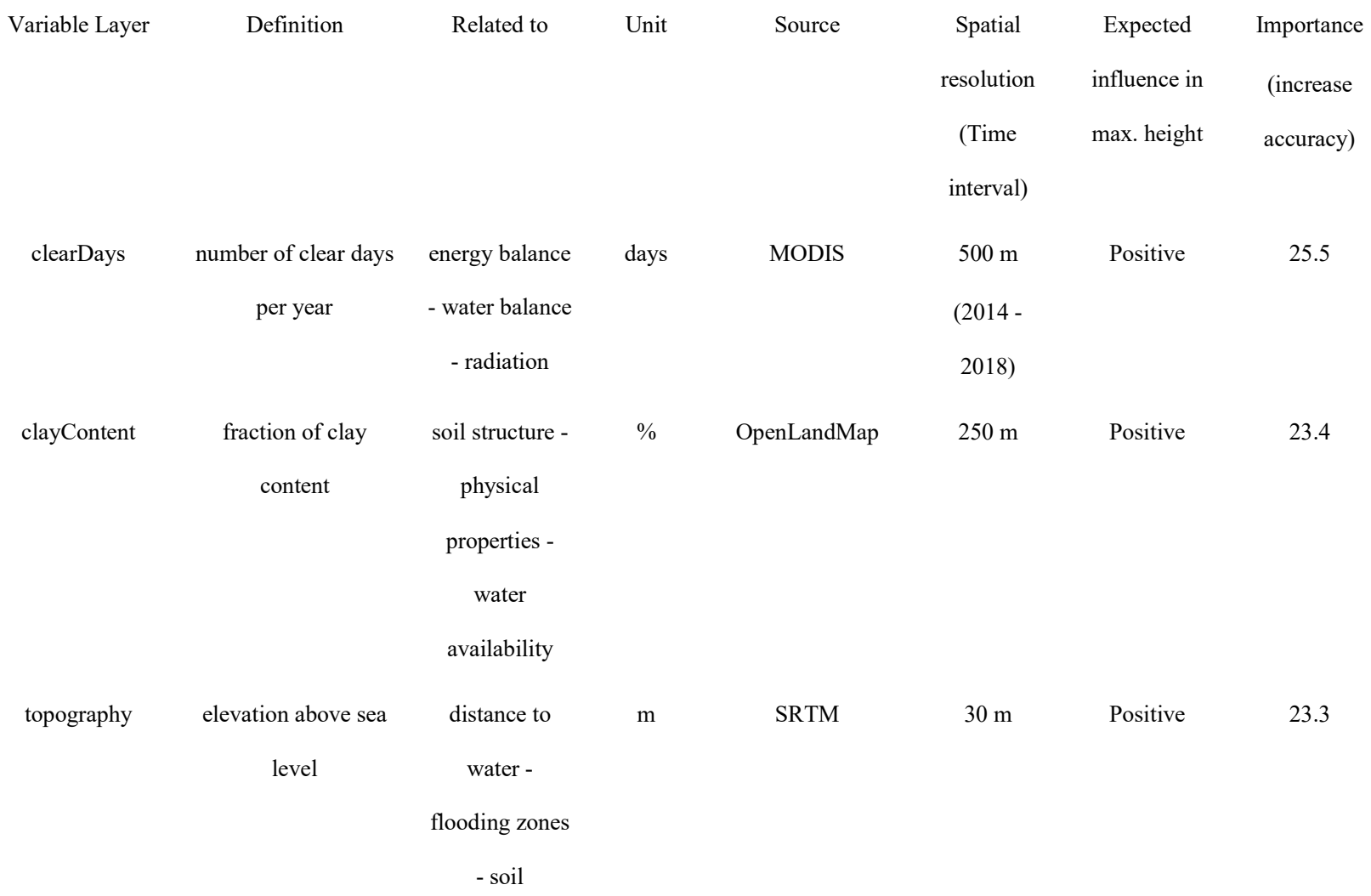




\begin{tabular}{|c|c|c|c|c|c|c|c|}
\hline pannual & $\begin{array}{l}\text { average annual } \\
\text { precipitation }\end{array}$ & $\begin{array}{l}\text { precipitation - } \\
\text { precipitation }\end{array}$ & $\mathrm{mm} \mathrm{y}^{-1}$ & WorldClim & $\begin{array}{l}30 \text { arc } \\
\text { seconds }\end{array}$ & Positive & 22.4 \\
\hline & & $\begin{array}{l}\text { intensity - } \\
\text { precipitation } \\
\text { distribution }\end{array}$ & & & & & \\
\hline pseason & $\begin{array}{l}\text { precipitation } \\
\text { seasonality }\end{array}$ & $\begin{array}{l}\text { precipitation - } \\
\text { precipitation } \\
\text { intensity - } \\
\text { precipitation } \\
\text { distribution }\end{array}$ & $\mathrm{mm}$ & WorldClim & $\begin{array}{l}30 \text { arc } \\
\text { seconds }\end{array}$ & Positive & 21.3 \\
\hline tseason & $\begin{array}{l}\text { temperature } \\
\text { seasonality }\end{array}$ & $\begin{array}{l}\text { temperature - } \\
\text { temperature } \\
\text { distribution }\end{array}$ & $\mathrm{C}$ & WorldClim & $\begin{array}{l}30 \text { arc } \\
\text { seconds }\end{array}$ & Negative & 21.3 \\
\hline uspeed & zonal speed (W-E) & $\begin{array}{l}\text { storms - } \\
\text { convective } \\
\text { winds }\end{array}$ & $\mathrm{m} \mathrm{s}^{-1}$ & ECM-RWF & $\begin{array}{l}0.25 \text { degrees } \\
(2014-2018)\end{array}$ & Negative & 21.1 \\
\hline pet & $\begin{array}{c}\text { potential } \\
\text { evapotranspiration }\end{array}$ & $\begin{array}{c}\text { energy balance } \\
\text { - water balance } \\
\text { - radiation - } \\
\text { vegetation } \\
\text { health - } \\
\text { anthropic } \\
\text { regions - soil } \\
\text { exposure }\end{array}$ & $\mathrm{mm} \mathrm{yr} \mathrm{r}^{-1}$ & TerraClimate & $\begin{array}{l}2.5 \text { arc } \\
\text { minutes } \\
(1990 \text { - } \\
2016)\end{array}$ & Positive & 20.2 \\
\hline fapar & $\begin{array}{l}\text { fraction of absorbed } \\
\text { photosynthetically } \\
\text { active radiation }\end{array}$ & $\begin{array}{l}\text { radiation - } \\
\text { vegetation } \\
\text { health - } \\
\text { anthropic } \\
\text { regions - soil } \\
\text { exposure }\end{array}$ & $\%$ & NOAA AVHRR & $\begin{array}{c}0.05 \text { degrees } \\
\text { (2016- } \\
\text { 2018) }\end{array}$ & Positive & 20.0 \\
\hline pwettest & $\begin{array}{l}\text { precipitation of the } \\
\text { wettest month }\end{array}$ & $\begin{array}{l}\text { precipitation - } \\
\text { precipitation }\end{array}$ & $\begin{array}{c}\mathrm{mm} \\
\text { month }^{-1}\end{array}$ & WorldClim & $\begin{array}{l}30 \text { arc } \\
\text { seconds }\end{array}$ & Negative & 19.9 \\
\hline
\end{tabular}




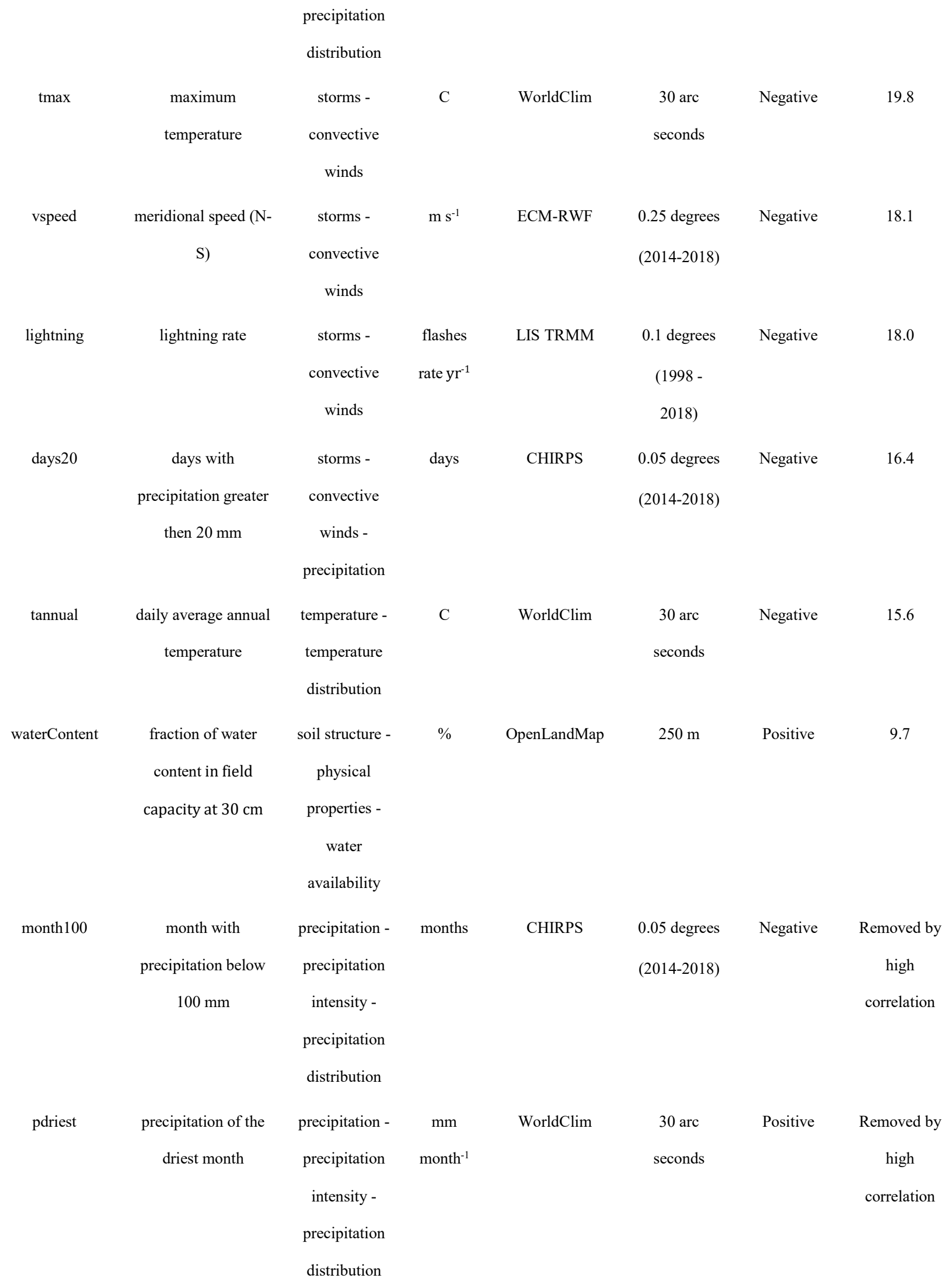


240 The random forest model obtained $\mathrm{MAE}=3.62 \mathrm{~m}, \mathrm{RMSE}=4.92 \mathrm{~m}$, and $\mathrm{R}^{2}=0.735$ (observed

241 versus predicted height plot is shown in Supplementary Figure 3; the R object is available to 242 download in https://doi.org/10.5281/zenodo.4061838). Mapped across the Brazilian Amazon the 243 model predicted maximum tree height above 70 meters in $56,747 \mathrm{~km}^{2}(1.03 \%$ of the area). Those 244 regions are concentrated in the Eastern Amazon, with trees achieving the greatest heights in the 245 northeastern portion of the Roraima biogeographic region (Fig. 3).

246 The lidar sampling design included old-growth, degraded and second-growth forests often mixed 247 in the same transect. Given the difficulties to accurately classify forest types and the mixture of 248 forest types within transects, we modeled all transects including second-growth and degraded 249 forests. In order to explore the potential effect of forest degradation, we repeated the random 250 forest model after removing low values of FAPAR $(<80 \%)$ that are associated with degraded 251 forests and anthropogenic regions - eliminating 133 transects. The spatial distributions for 252 maximum tree height persisted after removing these potential anthropogenic effects. Variable 253 importance was similar and consistent (Supplementary Table 1). 


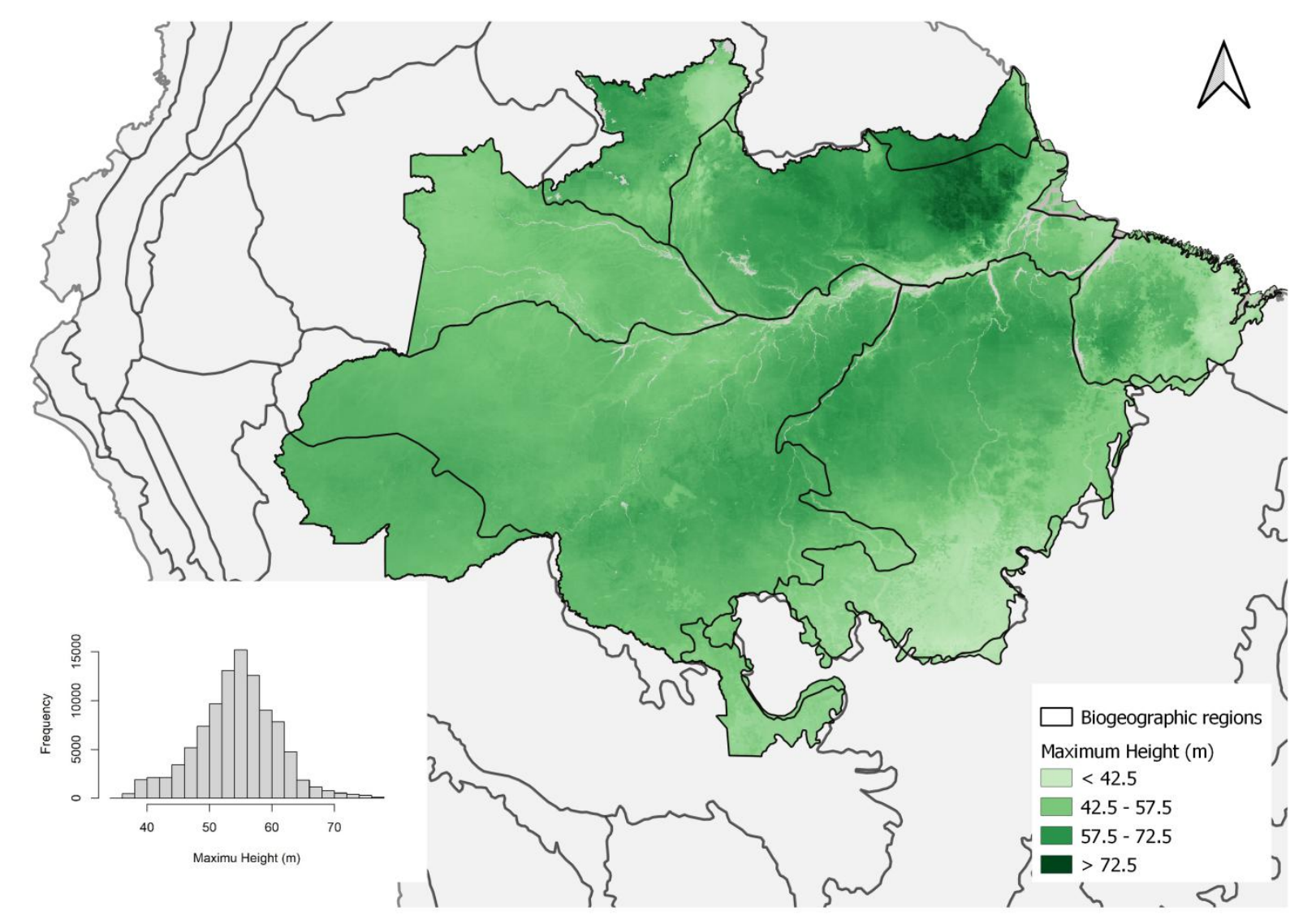

Figure 3. The maximum tree height distribution estimated by the random forests model based on

256 environmental variables. The map is available at https://doi.org/10.5281/zenodo.4036988.

257 The number of clear days was the strongest predictor of maximum height (Table 1). The shape of 258 this relation resembles a step function (Fig. 4), in which regions with the number of clear days

259 below 130 days per year support tall trees, with an abrupt decline in maximum height above this

260 level. An increase in soil clay content from $20 \%$ to $40 \%$ translated into a $7 \mathrm{~m}$ increase in

261 maximum height. Elevation was also a key predictor of tree height, with low-lying forests

262 growing $7 \mathrm{~m}$ lower than trees in terrains above $40 \mathrm{~m}$ above sea level. Our results also

263 demonstrate that mean annual precipitation was a key factor related to maximum height, with a

264 tolerance curve peaking at around 2,300 $\mathrm{mm} \mathrm{yr}^{-1}$ as optimal annual precipitation across the 
265 Brazilian Amazon. In comparison to these areas, we observe a $4 \mathrm{~m}$ decline in maximum tree 266 height in regions with annual precipitation below $1,500 \mathrm{~mm} \mathrm{yr}^{-1}$ or above 3,000 $\mathrm{mm} \mathrm{yr}^{-1}$. From 267 the intermediate importance variables, we highlight the zonal velocity (u-speed) and FAPAR 268 influencing height variation in ranges around $6 \mathrm{~m}$. 

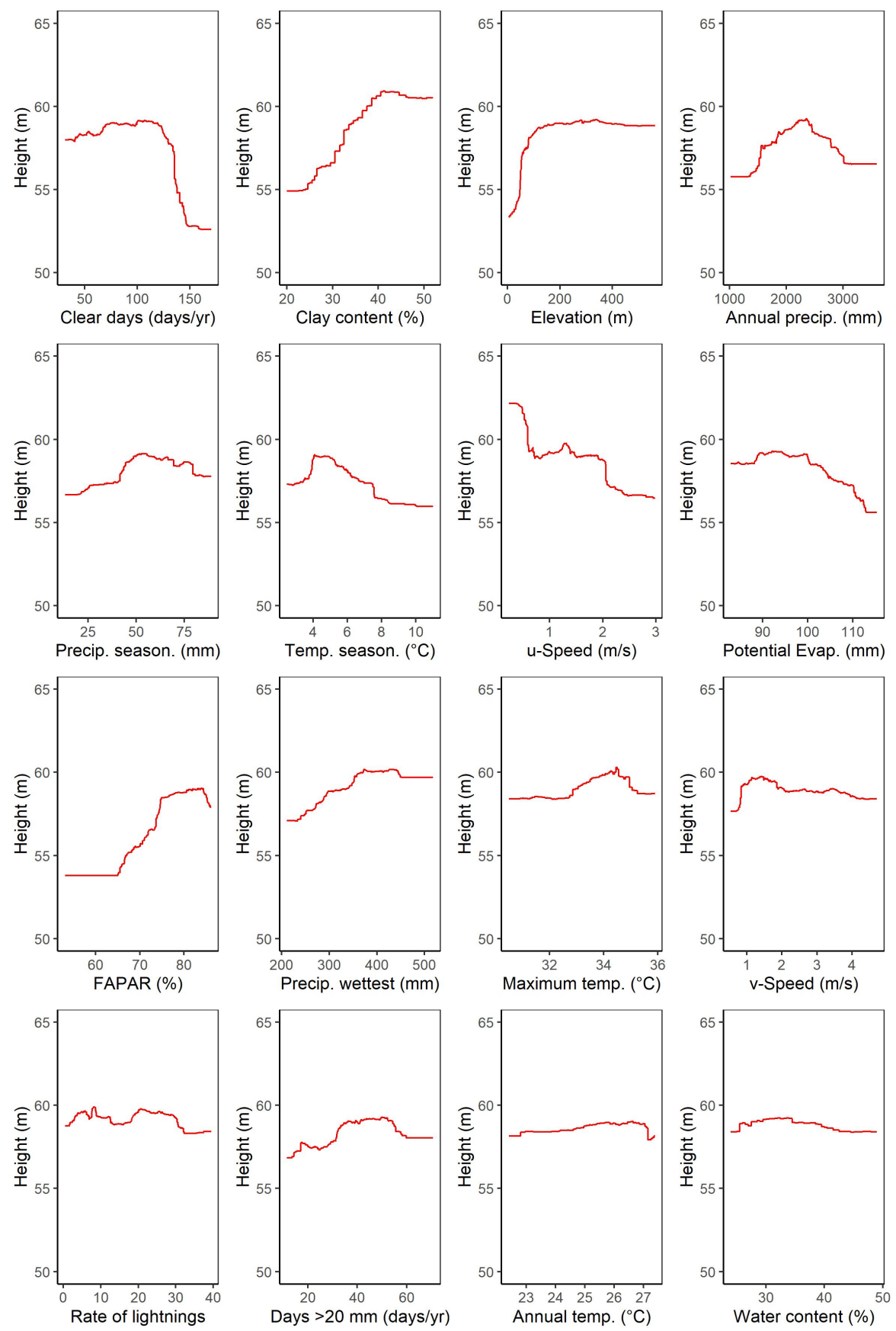

270 Figure 4. The marginal plot obtained for each environmental variable in the random forests

271 model, keeping other variables constant at the average value.

272 The results of the MaxEnt model focus on the occurrence of giant trees taller than 70 (the R

273 object is available to download in https://doi.org/10.5281/zenodo.4066653). The giant tall trees 
274 were found in conditions characterized by a much smaller set of environmental variables that

275 drove the large-scale patterns of maximum height (Fig. 5). The maximum entropy model shows

276 that the occurrence is dominated by wind speed (relative importance of $67.7 \%$ ). The second

277 most important driver of tall tree occurrence was the elevation above sea level (relative

278 importance of $12.3 \%$ ). The resulting map of predicted occurrence of the tallest trees in the

279 Amazon from the MaxEnt model shows that the probability of maximum tree height occurrence

280 is highest in northeastern Amazon (Fig. 6), more specifically in the Roraima and Guianan

281 Lowlands biogeographic regions. 

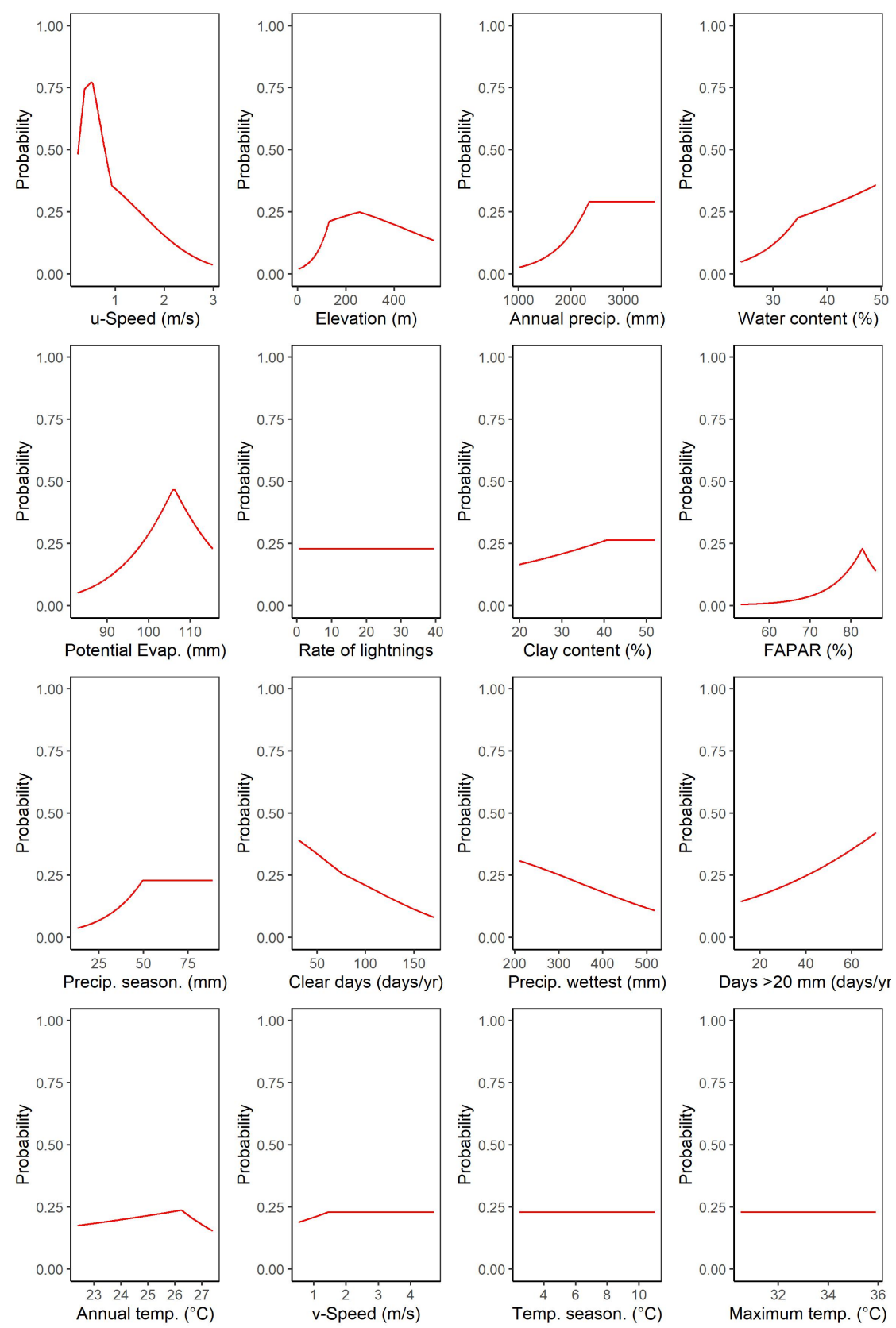

283 Figure 5. The marginal plot obtained for each environmental variable in the Maximum Entropy model, keeping others constant on the average. 


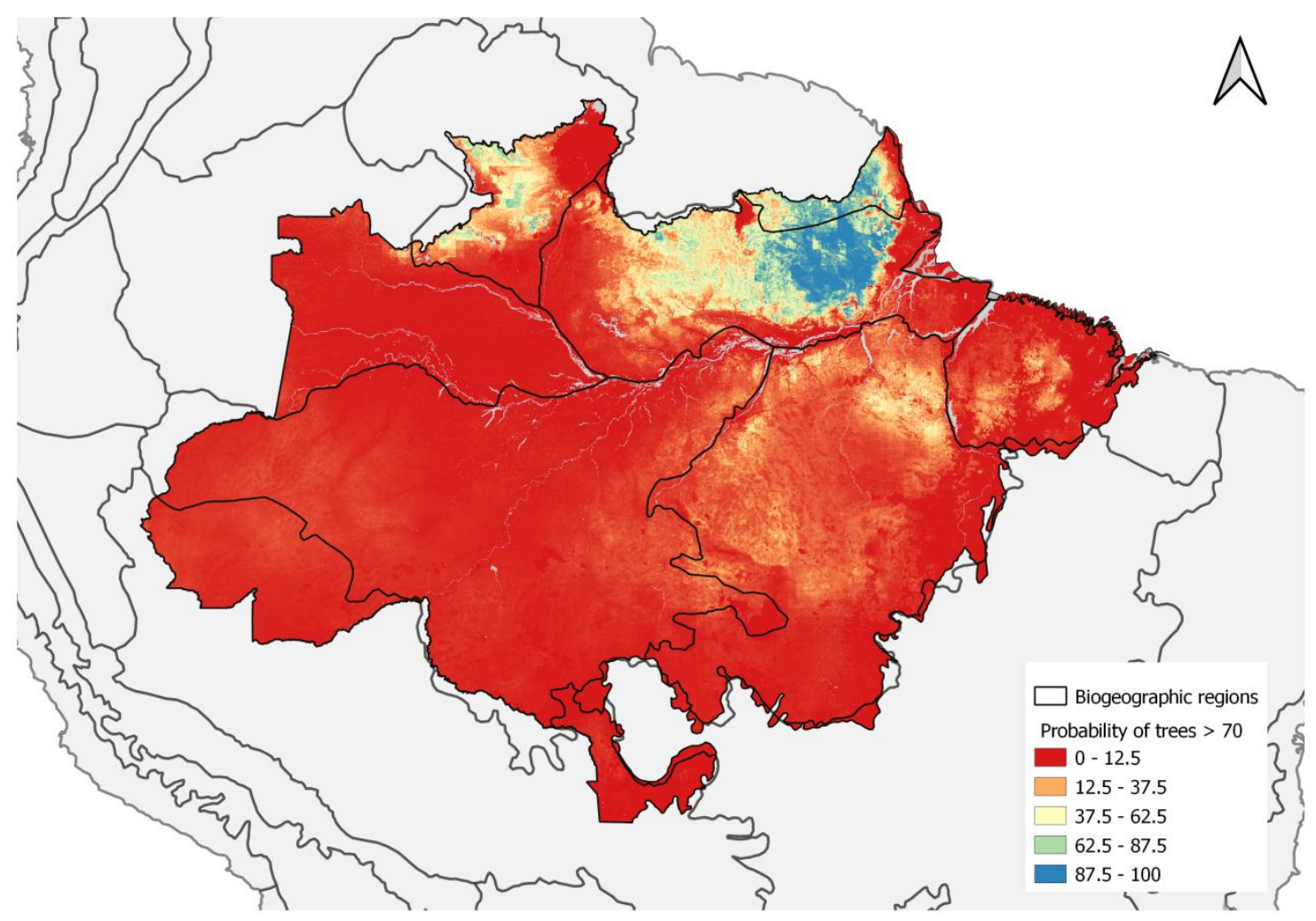

Figure 6. The probability of giant tree occurrence based on environmental conditions estimated

287 by the Maximum Entropy model. The map is available at

288 https://doi.org/10.5281/zenodo.4037101.

\section{Discussion}

290 We found that maximum tree height across the Brazilian Amazon was related to a large number

291 of environmental variables. The number of cloud free days stands out as the most relevant

292 variable to explain maximum height distribution, followed closely by wind speed, soil clay

293 content, elevation, precipitation and temperature seasonality, potential evapotranspiration, and

294 maximum temperature. In contrast, the distribution of giant trees $>70 \mathrm{~m}$ was strongly driven by

295 low wind speeds. 
Many environmental variables with complementary effects on species composition, as well as on their physiological and structural traits, play a crucial role in the tree lifespan (Muller-Landau, 2004) and, consequently, on height development. Previous studies have observed two large-scale gradients in the Amazon affecting forest composition and structure: one from the Guiana Shield to the Southwestern Amazon, related to variation in soil fertility, and another gradient from Colombia to the Southeastern Amazon, related to the length of the dry season (Baker et al. 2004; Malhi et al. 2006; ter Steege et al., 2006).

We found that maximum height was strongly related to the number of clear days, followed by soil clay content, elevation, annual precipitation and precipitation seasonality. An increase in cloud-free days is associated with an increase in direct solar radiation (Barkhordarian et al., 2015). Tree responses to direct solar radiation are dependent on the species and developmental

313 stage, with physiological and structural changes to maximize either growth or survival (Wright et 314 al., 2004; Nunes et al., 2019; Poorter \& Bongers, 2006). As trees grow taller, increasing leaf 315 water stress due to gravity and path length resistance can limit leaf expansion and photosynthesis, and consequently limit further height growth (Koch et al., 2004).

317 An increase in soil clay content also was associated with an increase in maximum height. In the 318 Amazon, clay content is often higher on flat terrain (Laurance et al., 1999) decreasing from 75\% 
to $5 \%$ when moving from the plateau areas to the valleys (Ferraz et al., 1998; Toledo et al., 2016). A previous study showed an increase in wood density from stands on sandy soils in valleys to

321 clayey soils on plateaus at a local scale in the Central Amazon, and lower tree mortality rates in

322 clayey soils (Toledo et al., 2016). We suggest that the well-structured clay soils allow trees to

323 obtain an additional volume of water during the dry season. Well structured clay soils are

324 common in the eastern Amazon, compared to central and western Amazon (Fisher et al., 2008;

325 Hodnett et al., 1997). The dimorphic root systems associated with deep structured clayey soils

326 can redistribute water from deep layers to the soil surface during periods of drought (Broedel et

327 al., 2017).

Elevation was also a key predictor of tree height, with low-lying forests growing potentially less than trees in terrains over $40 \mathrm{~m}$ a.s.1.. The topographic gradient is probably related to flooding in the low elevation transects. Rivers erode the terra firme terraces and create floodplains of 331 variable sizes dating to the Miocene, with terrace-floodplain elevation differences decreasing 332 eastwards from the Andes (Hamilton et al., 2007). The terrace and floodplain forests in the 333 Amazon also have differences related to species turnover, which reveals the micro-topography 334 effects on the tree survival rate in Amazonian forests (Asner et al., 2015). Due to higher turnover 335 on floodplains, trees live, on average, for less time and are less likely to achieve giant status.

336 Mean annual precipitation was also a key factor supporting the presence of tall trees. A tolerance

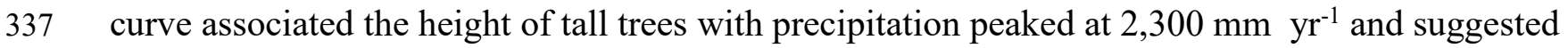
338 that areas too dry or too wet may both inhibit the growth of tall trees. We observed a decline in maximum tree height in regions with annual precipitation below 1,500 $\mathrm{mm} \mathrm{yr}^{-1}$ or above 3,000 $340 \mathrm{~mm} \mathrm{yr}^{-1}$. The availability of soil water depends on both precipitation and evapotranspiration, and 341 our results suggest that below $1,500 \mathrm{~mm} \mathrm{yr}^{-1}$ evapotranspiration may exceed precipitation in the 
342 Amazon leading to mortality by hydraulic failure for tall trees under drought

343 conditions (McDowell et al., 2008). Mean annual precipitation above 2,300 $\mathrm{mm} \mathrm{yr}^{-1}$ may be

344 related to excess water, and the combination of high precipitation and poorly drained soils may

345 result in anaerobic conditions with negative effects on tree growth and survival (Quesada et al.,

346 2009). Furthermore, greater precipitation tends to be related to the occurrence of storms and

347 strong winds associated with increases in tree mortality (Negrón-Juárez et al., 2018, Aleixo et al., 348 2019).

349 Conditions supporting giant trees

350 Low wind speed was the single most important predictor of the occurrence of the trees over $70 \mathrm{~m}$

351 in the Brazilian Amazon in the MaxEnt model. The fact that trees adapt to their local wind

352 environment and are shorter in windy locations has been widely observed in temperate

353 regions (Telewski, 2006, Bonnesoeur et al., 2016). A balance between tree structural strength

354 and wind shear forces contributes to set an upper limit to tree height development (Klein et al.,

355 2015). Wind driven damage and mortality could drive part of the pattern we observed across the

356 Amazon, with trees over $70 \mathrm{~m}$ tall having a 50-75\% likelihood of occurring in the calmest areas

357 but a sharply decreasing probability with stronger winds.

358 The spatial distribution we observed also aligned with observed disturbance rates, that are three

359 times higher in the Western compared to the the Eastern Amazon (Espírito-Santo et al., 2014).

360 Wind damage is most common from September to February (Negrón-Juárez et al., 2017) and

361 taller trees have higher rates of mortality in wind storms (Rifai et al., 2016). This suggests that

362 wind disturbance shapes the observed patterns of giant tree distribution. The importance of wind

363 speed was also apparent in the random forests model which showed a $9 \mathrm{~m}$ reduction in the 
364 estimated tree height from the calmest to the windiest areas. The zonal velocity (i.e. the east-west

365 component), which is the prevailing wind direction in the region, drives this pattern.

366 Because the maximum entropy model was highly sensitive to the effect of wind speed, we tested

367 the model excluding both wind speed variables. We found that the importance of variables

368 shifted to lightning (importance changed from 3 to 34), potential evapotranspiration (importance

369 changed from 4 to 18 ) and precipitation seasonality (importance changed from 0.5 to 15 ).

370 Secondary factors such elevation, annual precipitation and water content did not change after

371 removing wind speed. These shifts indicate that wind speed is indeed adding information.

372 Interestingly, our data showed that the lightning flash rate was only weakly related to maximum

373 forest height patterns in both the random forests and MaxEnt models. Despite being an important

374 cause of death of individual trees (Marra et al., 2014; Niklas, 1998) and the most important cause

375 of large tree deaths in a tropical forest in Panama (Yanoviak et al., 2019), lightning and

376 associated storms were not the dominant factor limiting the occurrence of the tallest trees in our 377 analysis.

378 The locations of the tall trees ( $>70 \mathrm{~m}$ - giant trees) in the eastern Amazon coincide with forests 379 that have a high basal area predicted by statistical modelling of permanent plot data (Malhi et al., 380 2006; ter Steege et al., 2006). Young soils nearer the Andes, as well as the sedimented and 381 flooded lowlands, are richer in nutrients, thereby supporting fast-growing, low wood density 382 species with high turnover rates and, as a result, the trees do not reach extremely large 383 sizes (Marra et al., 2014; Quesada et al., 2011; Phillips et al., 2004). Soil physical properties 384 combined with limited nutrient supply in eastern Amazon favor slow-growing species that invest 385 their resources in structures that can support taller and bigger trees with a long lifespan (Malhi et 386 al., 2004; Quesada et al., 2009). 
387 Current climate models differ in their predictions of large-scale changes in wind patterns.

388 However, warmer temperatures will mean that the air can hold more moisture, which will likely

389 make convective storms more intense. Whatever the change in environmental conditions, it is

390 likely to occur faster than trees can adapt. Our results showed that precipitation and temperature

391 have a lower importance than expected from previous studies. Nevertheless, changes in the

392 precipitation and radiation regimes (strongly linked to the number of cloudy days) could reshape

393 forest biomes. Ultimately, the association between environmental conditions and mechanisms of

394 natural selection are key to understanding the complexity of this process in a changing climate.

\section{Acknowledgements}

396 Funding was provided by the Coordenação de Aperfeiçoamento de Pessoal de Nível Superior

397 Brasil (CAPES; Finance Code 001); Conselho Nacional de Desenvolvimento Científico e

398 Tecnológico (Processes 403297/2016-8 and 301661/2019-7); Amazon Fund (grant 14.2.0929.1);

399 National Academy of Sciences and US Agency for International Development (grant AID-OAA-

400 A-11-00012); Universidade Federal dos Vales do Jequitinhonha e Mucuri (UFVJM); Instituto

$401 \quad$ Nacional de Pesquisas Espaciais (INPE);

402 D. Almeida was supported by the São Paulo Research Foundation (\#2018/21338-3 and

$403 \quad \# 2019 / 14697-0)$;

404

B. Gimenez, G. Spanner and N. Higuchi were supported by INCT-Madeiras da Amazônia and

405 Next Generation Ecosystem Experiments-Tropics (NGEE-Tropics), as part of DOE's Terrestrial

406 Ecosystem Science Program - Contract No. DE-AC02-05CH11231; 
T. Jackson and D. Coomes were supported by the UK Natural Environment Research Council grant NE/S010750/1;

M. Nunes was supported by the Academy of Finland (decision number 319905);

J. Rosette was supported by the Royal Society University Research Fellowship (URF\R\191014);

\section{References}

Abatzoglou, J. T., Dobrowski, S. Z., Parks, S. A., \& Hegewisch, K. C. (2018). TerraClimate a high-resolution global dataset of monthly climate and climatic water balance from 19582015. Scientific Data, 5(1). https://doi.org/10.1038/sdata.2017.191

Albergel, C., Dutra, E., Bonan, B., Zheng, Y., Munier, S., Balsamo, G., de Rosnay, P., MuñozSabater, J., \& Calvet, J.-C. (2019). Monitoring and Forecasting the Impact of the 2018 Summer Heatwave on Vegetation. Remote Sensing, 11(5), 520. https://doi.org/10.3390/rs11050520

Albrecht, R. I., Goodman, S. J., Buechler, D. E., Blakeslee, R. J., \& Christian, H. J. (2016). Where Are the Lightning Hotspots on Earth? Bulletin of the American Meteorological Society, 97(11), 2051-2068. https://doi.org/10.1175/bams-d-14-00193.1

Aleixo, I., Norris, D., Hemerik, L., Barbosa, A., Prata, E., Costa, F., \& Poorter, L. (2019). Amazonian rainforest tree mortality driven by climate and functional traits. Nature Climate Change, 9(5), 384-388. https://doi.org/10.1038/s41558-019-0458-0

Almeida, D. R. A., Stark, S. C., Schietti, J., Camargo, J. L. C., Amazonas, N. T., Gorgens, E. B., Rosa, D. M., Smith, M. N., Valbuena, R., Saleska, S., Andrade, A., Mesquita, R., Laurance, S. G., Laurance, W. F., Lovejoy, T. E., Broadbent, E. N., Shimabukuro, Y. E., Parker, G. G., Lefsky, M., ... Brancalion, P. H. S. (2019). Persistent effects of fragmentation on tropical rainforest canopy structure after 20yr of isolation. Ecological Applications, 29(6). https://doi.org/10.1002/eap.1952

Anderegg, W. R. L., Klein, T., Bartlett, M., Sack, L., Pellegrini, A. F. A., Choat, B., \& Jansen, S. (2016). Meta-analysis reveals that hydraulic traits explain cross-species patterns of droughtinduced tree mortality across the globe. Proceedings of the National Academy of Sciences, 113(18), 5024-5029. https://doi.org/10.1073/pnas.1525678113 
Andrade, M. S., Gorgens, E. B., Reis, C. R., Cantinho, R. Z., Assis, M., Sato, L., \& Ometto, J. P. H. B. (2018). Airborne laser scanning for terrain modeling in the amazon forest. Acta Amazonica, 48(4), 271-279. https://doi.org/10.1590/1809-4392201800132

Arsanjani, J. J., Vaz, E., Bakillah, M., \& Mooney, P. (2014). Towards initiating OpenLandMap founded on citizens' science: The current status of land use features of OpenStreetMap in Europe. International Conference on Geographic Information Science.

Asner, G. P., Powell, G. V. N., Mascaro, J., Knapp, D. E., Clark, J. K., Jacobson, J., KennedyBowdoin, T., Balaji, A., Paez-Acosta, G., Victoria, E., Secada, L., Valqui, M., \& Hughes, R. F. (2010). High-resolution forest carbon stocks and emissions in the Amazon. Proceedings of the National Academy of Sciences, 107(38), 16738-16742. https://doi.org/10.1073/pnas.1004875107

Asner, G. P. (2009). Tropical forest carbon assessment: integrating satellite and airborne mapping approaches. Environmental Research Letters, 4(3), 34009. https://doi.org/10.1088/1748-9326/4/3/034009

Asner, G. P., Anderson, C. B., Martin, R. E., Tupayachi, R., Knapp, D. E., \& Sinca, F. (2015). Landscape biogeochemistry reflected in shifting distributions of chemical traits in the Amazon forest canopy. Nature Geoscience, 8(7), 567-573.

Bae, S., Levick, S. R., Heidrich, L., Magdon, P., Leutner, B. F., Wöllauer, S., Serebryanyk, A., Nauss, T., Krzystek, P., Gossner, M. M., Schall, P., Heibl, C., Bässler, C., Doerfler, I., Schulze, E.-D., Krah, F.-S., Culmsee, H., Jung, K., Heurich, M., ... Müller, J. (2019). Radar vision in the mapping of forest biodiversity from space. Nature Communications, $10(1)$. https://doi.org/10.1038/s41467-019-12737-x

Baker, T. R., Phillips, O. L., Malhi, Y., Almeida, S., Arroyo, L., Fiore, A. Di, Erwin, T., Killeen, T. J., Laurance, S. G., Laurance, W. F., Lewis, S. L., Lloyd, J., Monteagudo, A., Neill, D. A., Patino, S., Pitman, N. C. A., Silva, J. N. M., Martinez, R. V., \& Hensberge, H. (2004). Variation in wood density determines spatial patterns in Amazonian forest biomass. Global Change Biology, 10(5), 545-562. https://doi.org/10.1111/j.1365-2486.2004.00751.x

Barkhordarian, A., Saatchi, S. S., Behrangi, A., Loikith, P. C., \& Mechoso, C. R. (2019). A Recent Systematic Increase in Vapor Pressure Deficit over Tropical South America. Scientific Reports, 9(1). https://doi.org/10.1038/s41598-019-51857-8

Bennett, A. C., McDowell, N. G., Allen, C. D., \& Anderson-Teixeira, K. J. (2015). Larger trees suffer most during drought in forests worldwide. Nature Plants, 1(10). https://doi.org/10.1038/nplants.2015.139 
Binkley, D., Stape, J. L., \& Ryan, M. G. (2004). Thinking about efficiency of resource use in forests. Forest Ecology and Management, 193(1-2), 5-16. https://doi.org/10.1016/j.foreco.2004.01.019

Bisht, G., \& Bras, R. L. (2010). Estimation of net radiation from the MODIS data under all sky conditions: Southern Great Plains case study. Remote Sensing of Environment, 114(7), 1522-1534. https://doi.org/10.1016/j.rse.2010.02.007

Bonnesoeur, V., Constant, T., Moulia, B., \& Fournier, M. (2016). Forest trees filter chronic wind-signals to acclimate to high winds. New Phytologist, 210(3), 850-860. https://doi.org/10.1111/nph.13836

Breiman, L. (2001). Random forests. Machine Learning, 45, 5-32.

Broedel, E., Tomasella, J., Cândido, L. A., \& von Randow, C. (2017). Deep soil water dynamics in an undisturbed primary forest in central Amazonia: Differences between normal years and the 2005 drought. Hydrological Processes, 31(9), 1749-1759. https://doi.org/10.1002/hyp.11143

Cao, M., \& Woodward, F. I. (2002). Net primary and ecosystem production and carbon stocks of terrestrial ecosystems and their responses to climate change. Global Change Biology, 4(2), 185-198. https://doi.org/10.1046/j.1365-2486.1998.00125.x

Chave, J., Piponiot, C., Maréchaux, I., de, F. H., Larpin, D., Fischer, F. J., Derroire, G., Vincent, G., \& Hérault, B. (2020). Slow rate of secondary forest carbon accumulation in the Guianas compared with the rest of the Neotropics. Ecol Appl, 30, e02004.

Clark, M. L., Clark, D. B., \& Roberts, D. A. (2004). Small-footprint lidar estimation of subcanopy elevation and tree height in a tropical rain forest landscape. Remote Sensing of Environment, 91(1), 68-89. https://doi.org/10.1016/j.rse.2004.02.008

Coomes, D. A., Dalponte, M., Jucker, T., Asner, G. P., Banin, L. F., Burslem, D. F. R. P., Lewis, S. L., Nilus, R., Phillips, O. L., Phua, M.-H., \& Qie, L. (2017). Area-based vs tree-centric approaches to mapping forest carbon in Southeast Asian forests from airborne laser scanning data. Remote Sensing of Environment, 194, 77-88. https://doi.org/10.1016/j.rse.2017.03.017

Coomes, D. A., Jenkins, K. L., \& Cole, L. E. S. (2006). Scaling of tree vascular transport systems along gradients of nutrient supply and altitude. Biology Letters, 3(1), 87-90. https://doi.org/10.1098/rsbl.2006.0551

Daubenmire, R. (1976). The use of vegetation in assessing the productivity of forest lands. The Botanical Review, 42(2), 115-143. https://doi.org/10.1007/BF02860720 
Drake, J. E., Tjoelker, M. G., Vårhammar, A., Medlyn, B., Reich, P. B., Leigh, A., Pfautsch, S., Blackman, C. J., López, R., Aspinwall, M. J., Crous, K. Y., Duursma, R. A., Kumarathunge, D., Kauwe, M. G. De, Jiang, M., Nicotra, A. B., Tissue, D. T., Choat, B., Atkin, O. K., \& Barton, C. V. M. (2018). Trees tolerate an extreme heatwave via sustained transpirational cooling and increased leaf thermal tolerance. Global Change Biology, 24(6), 2390-2402. https://doi.org/10.1111/gcb.14037

Enquist, B. J., Abraham, A. J., Harfoot, M. B. J., Malhi, Y., \& Doughty, C. E. (2020). The megabiota are disproportionately important for biosphere functioning. Nature Communications, 11(1). https://doi.org/10.1038/s41467-020-14369-y

Espírito-Santo, F. D. B., Gloor, M., Keller, M., Malhi, Y., Saatchi, S., Nelson, B., Junior, R. C. O., Pereira, C., Lloyd, J., Frolking, S., Palace, M., Shimabukuro, Y. E., Duarte, V., Mendoza, A. M., López-González, G., Baker, T. R., Feldpausch, T. R., Brienen, R. J. W., Asner, G. P., ... Phillips, O. L. (2014). Size and frequency of natural forest disturbances and the Amazon forest carbon balance. Nature Communications, 5, 1-6. https://doi.org/10.1038/ncomms4434

Farr, T. G., Rosen, P. A., Caro, E., Crippen, R., Duren, R., Hensley, S., Kobrick, M., Paller, M., Rodriguez, E., Roth, L., \& others. (2007). The shuttle radar topography mission. Reviews of Geophysics, 45(2).

Feldpausch, T. R., Lloyd, J., Lewis, S. L., Brienen, R. J. W. W., Gloor, M., Monteagudo Mendoza, A., Lopez-Gonzalez, G., Banin, L., Abu Salim, K., Affum-Baffoe, K., others, Alexiades, M., Almeida, S., Amaral, I., Andrade, A., Aragão, L. E. O. C., Araujo Murakami, A., Arets, E. J. M., Arroyo, L., ... Phillips, O. L. (2012). Tree height integrated into pantropical forest biomass estimates. Biogeosciences, 9(8), 3381-3403. https://doi.org/10.5194/bg-9-3381-2012

Ferraz, J., Ohta, S., \& Sales, P. C. de. (1998). Distribuição dos solos ao longo de dois transectos em floresta primária ao norte de Manaus (AM). Higuchi, N., Campos, MAA, Sampaio, PTB, and Dos Santos, J., Espaço Comunicaçao Ltda., Manaus, Brazil, 264.

Fick, S. E., \& Hijmans, R. J. (2017). WorldClim2: new 1-km spatial resolution climate surfaces for global land areas. International Journal of Climatology, 37(12), 4302-4315. https://doi.org/10.1002/joc.5086

Fisher, R. A., Williams, M., de Lourdes Ruivo, M., de Costa, A. L., \& Meir, P. (2008). Evaluating climatic and soil water controls on evapotranspiration at two Amazonian rainforest sites. Agricultural and Forest Meteorology, 148(6-7), 850-861. https://doi.org/10.1016/j.agrformet.2007.12.001

Funk, C., Peterson, P., Landsfeld, M., Pedreros, D., Verdin, J., Shukla, S., Husak, G., Rowland, J., Harrison, L., Hoell, A., \& Michaelsen, J. (2015). The climate hazards infrared 
precipitation with stations: a new environmental record for monitoring extremes. Scientific Data, 2(1). https://doi.org/10.1038/sdata.2015.66

Glenn, N. F., Spaete, L. P., Sankey, T. T., Derryberry, D. R., Hardegree, S. P., \& Mitchell, J. (2011). Errors in LiDAR-derived shrub height and crown area on sloped terrain. Journal of Arid Environments, 75(4), 377-382. https://doi.org/10.1016/j.jaridenv.2010.11.005

Görgens, E. B., Soares, C. P. B., Nunes, M. H., \& Rodriguez, L. C. E. (2016). Characterization of Brazilian forest types utilizing canopy height profiles derived from airborne laser scanning. Applied Vegetation Science, 19(3), 518-527. https://doi.org/10.1111/avsc.12224

Gorgens, E. B., Motta, A. Z., Assis, M., Nunes, M. H., Jackson, T., Coomes, D., Rosette, J., e Cruz Aragão, L. E. O., Ometto, J. P., Aragão, L. E. O. e. C., \& Ometto, J. P. (2019). The giant trees of the Amazon basin. Frontiers in Ecology and the Environment, 17(7), 373-374. https://doi.org/10.1002/fee.2085

Gu, L. (2003). Response of a Deciduous Forest to the Mount Pinatubo Eruption: Enhanced Photosynthesis. Science, 299(5615), 2035-2038. https://doi.org/10.1126/science.1078366

Hamilton, S. K., Kellndorfer, J., Lehner, B., \& Tobler, M. (2007). Remote sensing of floodplain geomorphology as a surrogate for biodiversity in a tropical river system (Madre de Dios Peru). Geomorphology, 89(1-2), 23-38. https://doi.org/10.1016/j.geomorph.2006.07.024

Hijmans, R. J., Cameron, S. E., Parra, J. L., Jones, P. G., \& Jarvis, A. (2005). Very high resolution interpolated climate surfaces for global land areas. International Journal of Climatology, 25(15), 1965-1978. https://doi.org/10.1002/joc.1276

Hodnett, M. G., Vendrame, I., Marques Filho, A. D. O., Oyama, M. D., \& Tomasella, J. (1997). Soil water storage and groundwater behaviour in a catenary sequence beneath forest in central Amazonia: I. Comparisons between plateau, slope and valley floor. Hydrology and Earth System Sciences Discussions, 1.

Jagels, R., Equiza, M. A., Maguire, D. A., \& Cirelli, D. (2018). Do tall tree species have higher relative stiffness than shorter species? American Journal of Botany, 105(10), 1617-1630. https://doi.org/10.1002/ajb2.1171

Kang, S., Running, S. W., Zhao, M., Kimball, J. S., \& Glassy, J. (2005). Improving continuity of MODIS terrestrial photosynthesis products using an interpolation scheme for cloudy pixels. International Journal of Remote Sensing, 26(8), 1659-1676. https://doi.org/10.1080/01431160512331326693

Klein, T., Randin, C., \& Körner, C. (2015). Water availability predicts forest canopy height at the global scale. Ecology Letters, 18(12), 1311-1320. https://doi.org/10.1111/ele.12525 
Koch, G. W., Sillett, S. C., Jennings, G. M., \& Davis, S. D. (2004). The limits to tree height. Nature, 428(6985), 851-854. https://doi.org/10.1038/nature02417

Larjavaara, M. (2013). The world's tallest trees grow in thermally similar climates. New Phytologist, 202(2), 344-349. https://doi.org/10.1111/nph.12656

Laurance, W. F., Fearnside, P. M., Laurance, S. G., Delamonica, P., Lovejoy, T. E., Merona, J. M. R., Chambers, J. Q., \& Gascon, C. (1999). Relationship between soils and Amazon forest biomass: a landscape-scale study. Forest Ecology and Management, 118(1-3), $127-$ 138. https://doi.org/10.1016/s0378-1127(98)00494-0

Lefsky, M. A. (2010). A global forest canopy height map from the moderate resolution imaging spectroradiometer and the geoscience laser altimeter system. Geophysical Research Letters, 37(15), 1-5. https://doi.org/10.1029/2010GL043622

Leitold, V., Keller, M., Morton, D. C., Cook, B. D., \& Shimabukuro, Y. E. (2015). Airborne lidar-based estimates of tropical forest structure in complex terrain: opportunities and tradeoffs for REDD+. Carbon balance and management, 10(1), 3. https://doi.org/10.1186/s13021-015-0013-x

Liaw, A., \& Wiener, M. (2002). Classification and Regression by randomForest. $R$ News 2(3), $18-22$.

Lindenmayer, D. B., \& Laurance, W. F. (2016). The Unique Challenges of Conserving Large Old Trees. Trends in Ecology \& Evolution, 31(6), 416-418. https://doi.org/10.1016/j.tree.2016.03.003

Liu, J., Liu, D., \& Alsdorf, D. (2014). Extracting Ground-Level DEM From SRTM DEM in Forest Environments Based on Mathematical Morphology. IEEE Transactions on Geoscience and Remote Sensing, 52(10), 6333-6340. https://doi.org/10.1109/tgrs.2013.2296232

Malhi, Y., Baker, T. R., Phillips, O. L., Almeida, S., Alvarez, E., Arroyo, L., Chave, J., Czimczik, C. I., Fiore, A. Di, Higuchi, N., Killeen, T. J., Laurance, S. G., Laurance, W. F., Lewis, S. L., Montoya, L. M. M., Monteagudo, A., Neill, D. A., Vargas, P. N., Patino, S., ... Lloyd, J. (2004). The above-ground coarse wood productivity of 104 Neotropical forest plots. Global Change Biology, 10(5), 563-591. https://doi.org/10.1111/j.1529-8817.2003.00778.x

Malhi, Y., Wood, D., Baker, T. R., Wright, J., Phillips, O. L., Cochrane, T., Meir, P., Chave, J., Almeida, S., Arroyo, L., \& others. (2006). The regional variation of aboveground live biomass in old-growth Amazonian forests. Global Change Biology, 12(7), 1107-1138. https://doi.org/10.1111/j.1365-2486.2006.01120.x 
Marra, D. M., Chambers, J. Q., Higuchi, N., Trumbore, S. E., Ribeiro, G. H. P. M., dos Santos, J., Negrón-Juárez, R. I., Reu, B., \& Wirth, C. (2014). Large-Scale Wind Disturbances Promote Tree Diversity in a Central Amazon Forest. PLoS ONE, 9(8), e103711. https://doi.org/10.1371/journal.pone.0103711

Marvin, D. C., Asner, G. P., Knapp, D. E., Anderson, C. B., Martin, R. E., Sinca, F., \& Tupayachi, R. (2014). Amazonian landscapes and the bias in field studies of forest structure and biomass. Proceedings of the National Academy of Sciences, 111(48), E5224--E5232. https://doi.org/10.1073/pnas.1412999111

Mason, P. J., Zillman, J. W., Simmons, A., Lindstrom, E. J., Harrison, D. E., Dolman, H., Bojinski, S., Fischer, A., Latham, J., Rasmussen, J., \& others. (2010). Implementation plan for the global observing system for climate in support of the UNFCCC (2010 Update). In UNFCCC (Ed.), Conference of the Parties (COP). WMO, IOC, UNEP, ICSU.

McDowell, N., Pockman, W. T., Allen, C. D., Breshears, D. D., Cobb, N., Kolb, T., Plaut, J., Sperry, J., West, A., Williams, D. G., \& Yepez, E. A. (2008). Mechanisms of plant survival and mortality during drought: why do some plants survive while others succumb to drought? New Phytologist, 178(4), 719-739. https://doi.org/10.1111/j.1469-8137.2008.02436.x

McDowell, N. G., \& Allen, C. D. (2015). Darcy's law predicts widespread forest mortality under climate warming. Nature Climate Change, 5(7), 669-672. https://doi.org/10.1038/nclimate2641

Moles, A. T., Warton, D. I., Warman, L., Swenson, N. G., Laffan, S. W., Zanne, A. E., Pitman, A., Hemmings, F. A., \& Leishman, M. R. (2009). Global patterns in plant height. Journal of Ecology, 97(5), 923-932.

Morrone, J. J. (2014). Biogeographical regionalisation of the Neotropical region. Zootaxa, 3782(1), 1. https://doi.org/10.11646/zootaxa.3782.1.1

Muller-Landau, H. C. (2004). Interspecific and Inter-site Variation in Wood Specific Gravity of Tropical Trees. Biotropica, 36(1), 20-32. https://doi.org/10.1111/j.17447429.2004.tb00292.x

Negrón-Juárez, R. I., Jenkins, H. S., Raupp, C. F. M., Riley, W. J., Kueppers, L. M., Magnabosco Marra, D., Ribeiro, G. H. P. M., Monteiro, M. T. F., Candido, L. A., Chambers, J. Q., \& Higuchi, N. (2017). Windthrow Variability in Central Amazonia. Atmosphere, 8(2). https://doi.org/10.3390/atmos 8020028

Negrón-Juárez, R. I., Holm, J. A., Marra, D. M., Rifai, S. W., Riley, W. J., Chambers, J. Q., Koven, C. D., Knox, R. G., McGroddy, M. E., Di Vittorio, A. V., Urquiza-Muñoz, J., TelloEspinoza, R., Muñoz, W. A., Ribeiro, G. H. P. M., \& Higuchi, N. (2018). Vulnerability of 
Amazon forests to storm-driven tree mortality. Environmental Research Letters, 13(5). https://doi.org/10.1088/1748-9326/aabe9f

Niklas, K. J. (1998). The influence of gravity and wind on land plant evolution. Review of Palaeobotany and Palynology, 102(1-2), 1-14. https://doi.org/10.1016/s00346667(98)00011-6

Niklas, K. J. (2007). Maximum plant height and the biophysical factors that limit it. Tree Physiology, 27(3), 433-440. https://doi.org/10.1093/treephys/27.3.433

Nunes, M. H., Both, S., Bongalov, B., Brelsford, C., Khoury, S., Burslem, D. F. R. P., Philipson, C., Majalap, N., Riutta, T., Coomes, D. A., \& Cutler, M. E. J. (2019). Changes in leaf functional traits of rainforest canopy trees associated with an El Niño event in Borneo. Environmental Research Letters, 14(8), 85005. https://doi.org/10.1088/1748-9326/ab2eae

Olauson, J. (2018). ERA5: The new champion of wind power modelling? Renewable Energy, 126, 322-331. https://doi.org/10.1016/j.renene.2018.03.056

Phillips, O. L., Baker, T. R., Arroyo, L., Higuchi, N., Killeen, T. J., Laurance, W. F., Lewis, S. L., Lloyd, J., Malhi, Y., Monteagudo, A., \& others. (2004). Pattern and process in Amazon tree turnover, 1976-2001. Philosophical Transactions of the Royal Society of London. Series B: Biological Sciences, 359(1443), 381-407.

Phillips, S. J., Anderson, R. P., \& Schapire, R. E. (2006). Maximum entropy modeling of species geographic distributions. Ecological Modelling, 190(3-4), 231-259.

https://doi.org/10.1016/j.ecolmodel.2005.03.026

Poorter, L., \& Bongers, F. (2006). Leaf traits are good predictors of plant performance across 53 rain forest species. Ecology, 87(7), 1733-1743.

Powers, J. S., Vargas-G, G., Brodribb, T. J., Schwartz, N. B., Perez-Aviles, D., Smith-Martin, C. M., Becknell, J. M., Aureli, F., Blanco, R., Calderón-Morales, E., Calvo-Alvarado, J. C., Calvo-Obando, A. J., Chavarr '’ia, M. M., Carvajal-Vanegas, D., Jiménez-Rodr〉’iguez, C. D., Chacon, E. M., Schaffner, C. M., Werden, L. K., Xu, X., \& Medvigy, D. (2020). A catastrophic tropical drought kills hydraulically vulnerable tree species. Global Change Biology. https://doi.org/10.1111/gcb.15037

Quesada, C. A., Lloyd, J., Anderson, L. O., Fyllas, N. M., Schwarz, M., \& Czimczik, C. I. (2011). Soils of Amazonia with particular reference to the RAINFOR sites. Biogeosciences, $8(6)$, 1415-1440. https://doi.org/10.5194/bg-8-1415-2011

Quesada, C. A., Lloyd, J., Schwarz, M., Baker, T. R., Phillips, O. L., Patiño, S., Czimczik, C., Hodnett, M. G., Herrera, R., Arneth, A., \& others. (2009). Regional and large-scale patterns 
Ramon, J., Lledó, L., Torralba, V., Soret, A., \& Doblas-Reyes, F. J. (2019). What global reanalysis best represents near-surface winds? Quarterly Journal of the Royal Meteorological Society, 145(724), 3236-3251. https://doi.org/10.1002/qj.3616

Rifai, S. W., Urquiza Muñoz, J. D., Negrón-Juárez, R. I., Ramírez Arévalo, F. R., Tello-Espinoza, R., Vanderwel, M. C., Lichstein, J. W., Chambers, J. Q., \& Bohlman, S. A. (2016). Landscape-scale consequences of differential tree mortality from catastrophic wind disturbance in the Amazon. Ecological Applications, 26(7), 2225-2237.

Rowland, L., da Costa, A. C. L., Galbraith, D. R., Oliveira, R. S., Binks, O. J., Oliveira, A. A. R., Pullen, A. M., Doughty, C. E., Metcalfe, D. B., Vasconcelos, S. S., Ferreira, L. V, Malhi, Y., Grace, J., Mencuccini, M., \& Meir, P. (2015). Death from drought in tropical forests is triggered by hydraulics not carbon starvation. Nature, 528(7580), 119-122. https://doi.org/10.1038/nature15539

Rueda, M., Godoy, O., \& Hawkins, B. A. (2016). Spatial and evolutionary parallelism between shade and drought tolerance explains the distributions of conifers in the conterminous United States. Global Ecology and Biogeography, 26(1), 31-42. https://doi.org/10.1111/geb.12511

Sakschewski, B., von Bloh, W., Boit, A., Poorter, L., Peña-Claros, M., Heinke, J., Joshi, J., \& Thonicke, K. (2016). Resilience of Amazon forests emerges from plant trait diversity. Nature Climate Change, 6(11), 1032-1036. https://doi.org/10.1038/nclimate3109

Scheffer, M., Xu, C., Hantson, S., Holmgren, M., Los, S. O., van, N. E. H., \& van Nes, E. H. (2018). A global climate niche for giant trees. Global Change Biology, 24(7), 2875-2883. https://doi.org/10.1111/gcb.14167

Schimel, D., Pavlick, R., Fisher, J. B., Asner, G. P., Saatchi, S., Townsend, P., Miller, C., Frankenberg, C., Hibbard, K., \& Cox, P. (2015). Observing terrestrial ecosystems and the carbon cycle from space. Global Change Biology, 21(5), 1762-1776. https://doi.org/10.1111/gcb.12822

Seguro, J. V., \& Lambert, T. W. (2000). Modern estimation of the parameters of the Weibull wind speed distribution for wind energy analysis. Journal of Wind Engineering and Industrial Aerodynamics, 85(1), 75-84. https://doi.org/10.1016/S0167-6105(99)00122-1

Simard, M., Pinto, N., Fisher, J. B., \& Baccini, A. (2011). Mapping forest canopy height globally with spaceborne lidar. Journal of Geophysical Research: Biogeosciences, 116(4), 1-12. https://doi.org/10.1029/2011JG001708 
Stropp, J., Umbelino, B., Correia, R. A., Campos-Silva, J. V, Ladle, R. J., \& Malhado, A. C. M. (2020). The ghosts of forests past and future: deforestation and botanical sampling in the Brazilian Amazon. Ecography. https://doi.org/10.1111/ecog.05026

Takle, E. S., \& Brown, J. M. (1978). Note on the use of Weibull statistics to characterize wind speed data. Journal of Applied Meteorology, 17(4, Apr. 1978), 556-559. https://doi.org/10.1175/1520-0450(1978)017<0556:notuow>2.0.co;2

Tao, S., Guo, Q., Li, C., Wang, Z., \& Fang, J. (2016). Global patterns and determinants of forest canopy height. Ecology, 97(12), 3265-3270. https://doi.org/10.1002/ecy.1580

Tao, X., Liang, S., He, T., \& Jin, H. (2016). Estimation of fraction of absorbed photosynthetically active radiation from multiple satellite data: Model development and validation. Remote Sensing of Environment, 184, 539-557. https://doi.org/10.1016/j.rse.2016.07.036

Tejada, G., Görgens, E. B., Espírito-Santo, F. D. B., Cantinho, R. Z., \& Ometto, J. P. (2019). Evaluating spatial coverage of data on the aboveground biomass in undisturbed forests in the Brazilian Amazon. Carbon Balance and Management, 14(1). https://doi.org/10.1186/s13021-019-0126-8

Telewski, F. W. (2006). A unified hypothesis of mechanoperception in plants. American Journal of Botany, 93(10), 1466-1476. https://doi.org/10.3732/ajb.93.10.1466

ter Steege, H., Pitman, N. C. A., Phillips, O. L., Chave, J., Sabatier, D., Duque, A., Molino, J.-F., Prévost, M.-F., Spichiger, R., Castellanos, H., von Hildebrand, P., \& Vásquez, R. (2006). Continental-scale patterns of canopy tree composition and function across Amazonia. Nature, 443(7110), 444-447. https://doi.org/10.1038/nature05134

Toledo, J. J., Castilho, C. V, Magnusson, W. E., \& Nascimento, H. E. M. (2016). Soil controls biomass and dynamics of an Amazonian forest through the shifting of species and traits. Brazilian Journal of Botany, 40(2), 451-461. https://doi.org/10.1007/s40415-016-0351-2

Tuomisto, H., Van doninck, J., Ruokolainen, K., Moulatlet, G. M., Figueiredo, F. O. G. G., Sirén, A., Cárdenas, G., Lehtonen, S., Zuquim, G., doninck, J. Van, Ruokolainen, K., Moulatlet, G. M., Figueiredo, F. O. G. G., Sirén, A., Cárdenas, G., Lehtonen, S., \& Zuquim, G. (2019). Discovering floristic and geoecological gradients across Amazonia. Journal of Biogeography, 46(8), 1734-1748. https://doi.org/10.1111/jbi.13627

van Gelder, H. A., Poorter, L., \& Sterck, F. J. (2006). Wood mechanics allometry, and lifehistory variation in a tropical rain forest tree community. New Phytologist, 171(2), 367-378. https://doi.org/10.1111/j.1469-8137.2006.01757.x 
Vanclay, J. K. (1992). Assessing site productivity in tropical moist forests: a review. Forest Ecology and Management, 54(1-4), 257-287. https://doi.org/10.1016/0378-1127(92)900174

Williams, A. P., Allen, C. D., Macalady, A. K., Griffin, D., Woodhouse, C. A., Meko, D. M., Swetnam, T. W., Rauscher, S. A., Seager, R., Grissino-Mayer, H. D., Dean, J. S., Cook, E. R., Gangodagamage, C., Cai, M., \& McDowell, N. G. (2012). Temperature as a potent driver of regional forest drought stress and tree mortality. Nature Climate Change, 3(3), 292-297. https://doi.org/10.1038/nclimate1693

Wright, I. J., Reich, P. B., Westoby, M., Ackerly, D. D., Baruch, Z., Bongers, F., CavenderBares, J., Chapin, T., Cornelissen, J. H., Diemer, M., Flexas, J., Garnier, E., Groom, P. K., Gulias, J., Hikosaka, K., Lamont, B. B., Lee, T., Lee, W., Lusk, C., ... Villar, R. (2004). The worldwide leaf economics spectrum. Nature, 428, 821-827.

Yang, Y., Saatchi, S., Xu, L., Yu, Y., Lefsky, M., White, L., Knyazikhin, Y., \& Myneni, R. (2016). Abiotic Controls on Macroscale Variations of Humid Tropical Forest Height. Remote Sensing, 8(6), 494. https://doi.org/10.3390/rs8060494

Yanoviak, S. P., Gora, E. M., Bitzer, P. M., Burchfield, J. C., Muller-Landau, H. C., Detto, M., Paton, S., \& Hubbell, S. P. (2019). Lightning is a major cause of large tree mortality in a lowland neotropical forest. New Phytologist, 225(5), 1936-1944.

https://doi.org/10.1111/nph.16260 